\title{
Contents volume 16 (1998)
}

Guest-editorial: Peering into the mist and struggling through it - the education and training of the future information professional

I.M. Johnson

Differentiated competencies for graduate and undergraduate levels: needed transformation of the information study programs

S. Rehman, N.S.A. Karim, A.S. Chaudhry

Educating future librarians in Pakistan - a library educator's perspective S.J. Haider

Education for collection management: ending before it ever really started, or only just beginning?

J. Kennedy

Profiling librarians with the Myers-Briggs Type Indicator: studies in self selection and type stability

J. Agada

The health information practitioner as learner and educator

C. Urquhart, S. Hornby, T. Rogers and D. Bawden

Book reviews

Identifying the transferable skills of information professionals through mentoring Jane Farmer and Fiona Campbell

A career progression survey of graduates of the Postgraduate Diploma/MSc in Information Analysis

Rita Marcella and Graeme Baxter

Roadmaps for the Highway: the evaluation of an information literacy training programme for South African students

Karin de Jager and Mary Nassimbeni

Education for Library and Information Science at Kuwait University

(Short communication)

Dr. Taghreed Alqudsi-Ghabra and Dr. Hussain Al-Ansari

Book reviews

News 
The future demand for information professionals in Europe

Nick Moore

A survey of the institutions in Asia and the Pacific offering library and information studies through distance learning

Somsuang Prudtikul

Human resource development for information societies - an Asian perspective

Edward Lim

UNESCO and human resource development for the 'Information Society'

Ian M. Johnson

Preparing Information Professionals for the Next Century

Robert D. Stueart

Establishment of a LIS research and education network in the Republic of South Africa A project with roots in the FID/ET committee work (Short Communication)

Irene Wormell

Book reviews

News

Breaking down the barriers: the place of gender equity in the ILS curriculum Anne Goulding and Marigold Cleeve

The attitudes of undergraduate Information Management students to seminars:

a qualitative and a quantitative analysis

Clive Cochrane

Web-based virtual classrooms: a model for LIS education

Linda Main

Bibliometrics-Informetrics and other quantitative subjects in Library and Information Science curricula in Spain

Evaristo Jiménez-Contreras and Antonio Pulgarín-Guerrero

Book reviews

News

Author index volume 16 